\title{
1 Coarse woody debris and the carbon balance of a moderately disturbed forest
}

3 Amy V.Schmid ${ }^{\mathrm{a}}$, Christoph S. Vogel ${ }^{\mathrm{b}}$, Eli Liebmann ${ }^{\mathrm{c}}$, Peter S. Curtis ${ }^{\mathrm{d}}$, Christopher M. Gough ${ }^{\mathrm{a}^{*}}$

$5 \quad{ }^{a}$ Virginia Commonwealth University, Department of Biology, Richmond, VA 23284-2012, USA

$6 \quad{ }^{\mathrm{b}}$ University of Michigan, Biological Station \& Department of Ecology and Evolutionary

7 Biology, Pellston, MI 49769, USA

$8 \quad$ c Macalester College; 1600 Grand Ave., Saint Paul, MN 55105, USA

$9{ }^{\mathrm{d}}$ Ohio State University, Department of Evolution, Ecology and Organismal Biology, Columbus,

10 OH 43210, USA

11

12

$13 *$ Author for correspondence:

14 Christopher M. Gough

15 Virginia Commonwealth University

16 Department of Biology

$17 \quad$ Box 842012

181000 W. Cary Street

19 Richmond, VA 23284-2012

20 Phone: 804-827-8596

21 Email: cmgough@ vcu.edu

Schmid et al. - Woody Debris in a Moderately Disturbed Forest, 1 


\section{Abstract}

23 Forested landscapes are shaped by disturbances varying in severity and source. Moderate

24 disturbance from weather, pathogens, insects, and age-related senescence that kills only a subset

25 of canopy trees may increase standing woody debris and alter the contribution of coarse woody

26 debris (CWD) to total ecosystem respiration $\left(\mathrm{R}_{\mathrm{E}}\right)$. However, woody debris carbon $(\mathrm{C})$ dynamics

27 are rarely examined following moderate disturbances that increase standing dead wood pools.

28 We used an experimental manipulation of moderate disturbance in an upper Great Lakes forest

29 to: 1) examine multi-year changes in CWD mass through a moderate disturbance; 2) quantify in

30 situ CWD respiration during different stages of decay for downed and standing woody debris

31 and; 3) estimate the annual contribution of CWD respiration to the ecosystem $\mathrm{C}$ balance through

32 comparison with $\mathrm{R}_{\mathrm{E}}$ and net ecosystem production (NEP). Six years following disturbance, we

33 found that the standing dead wood mass of $24.5 \mathrm{Mg} \mathrm{C} \mathrm{ha}^{-1}$ was an order of magnitude greater

34 than downed woody debris mass and a large source of ecosystem C flux. Instantaneous in situ

35 respiration rates from standing and minimally decayed downed woody debris were not

36 significantly different from one another. Separate estimates of ecosystem CWD respiration of 1.1

37 to $2.1 \mathrm{Mg} \mathrm{C} \mathrm{ha}^{-1} \mathrm{yr}^{-1}$ six years following disturbance were comparable in magnitude to NEP and

$38 \quad 12.5 \%$ to $23.8 \%$ of $\mathrm{R}_{\mathrm{E}}$, representing a substantial increase relative to pre-disturbance levels.

39 Ecosystem respiration and NEP were stable following moderate disturbance even though

40 ecosystem CWD respiration increased substantially, suggesting a reduction in the respiratory $\mathrm{C}$

41 contribution from other sources. We conclude that standing and downed CWD can be essential

42 components of the ecosystem $\mathrm{C}$ balance following moderate severity disturbance.

Schmid et al. - Woody Debris in a Moderately Disturbed Forest, 2 
44 Keywords: Coarse woody debris; Disturbance; Carbon cycling; Respiration; Wood 45 decomposition; Standing woody debris

46

47

48

49

50

51

52

53

54

55

56

Schmid et al. - Woody Debris in a Moderately Disturbed Forest, 3 


\section{Introduction}

Forest disturbances alter the balance between ecosystem carbon $(\mathrm{C})$ uptake and loss, and

59 are primary determinants of the terrestrial C balance (Bond-Lamberty et al., 2007; Gough et al.,

60 2007; Amiro et al., 2010; Pan et al., 2011). Tree mortality from disturbance may affect

61 ecosystem $\mathrm{C}$ balance in two ways: by reducing the amount of $\mathrm{C}$ fixed via canopy photosynthesis

62 (or gross primary production, GPP), and by altering the quantity of C lost through ecosystem

63 respiration $\left(\mathrm{R}_{\mathrm{E}}\right)$, particularly as detritus-fueled microbial respiration increases (Liu et al., 2006;

64 Harmon et al., 2011). The difference between these two large opposing $\mathrm{C}$ fluxes determines

65 ecosystem $\mathrm{C}$ balance, or net ecosystem production (NEP), with a small post-disturbance change

66 in either GPP or $\mathrm{R}_{\mathrm{E}}$ potentially causing large alterations in NEP. Numerous studies show that

67 tree mortality can considerably reduce NEP, with some forests becoming C sources immediately

68 after severe, stand-replacing disturbance (Janisch and Harmon, 2002; Amiro et al., 2010;

69 Harmon et al., 2011; Hicke et al., 2012). The effects of moderate disturbances that kill only a

70 subset of canopy trees - such as those caused by insect pests, pathogens, and severe weather - on

71 NEP are less certain even as lower severity disturbances increase in frequency and extent in

72 many forested regions (Amiro et al., 2010). Coarse woody debris (CWD), defined here as

73 standing and downed dead wood $>10 \mathrm{~cm}$ diameter, is an important source of detritus following

74 disturbance, but is often unaccounted in estimates of $\mathrm{R}_{\mathrm{E}}$ and, as a result, the extent to which

75 CWD C cycling dynamics following disturbance alter ecosystem $\mathrm{C}$ balance is poorly understood

76 (Amiro et al., 2010; Harmon et al., 2011; Renninger et al., 2014).

77 Coarse woody debris C cycling dynamics are most thoroughly characterized for the

78 extreme end-members on the disturbance severity continuum, with most prior work conducted

79 severely and minimally disturbed forests (Gough et al., 2007; Harmon et al., 2011); considerably

Schmid et al. - Woody Debris in a Moderately Disturbed Forest, 4 
80 less is known about CWD C cycling dynamics following moderate disturbances that kill a

81 substantial fraction of, but not all, canopy trees within an ecosystem (Renninger et al., 2014).

82 Studies conducted in recently undisturbed forests show that CWD is a relatively small C pool

83 that contributes little to $\mathrm{R}_{\mathrm{E}}$ and thus minimally affects NEP (Harmon et al., 2004; Janisch et al.,

84 2005; Liu et al., 2006; Gough et al., 2007; Luyssaert et al., 2008; Tang et al., 2008). Following

85 severe, stand-replacing disturbance, CWD is a primary substrate for microbial decomposition

86 and, therefore, a large component of $\mathrm{R}_{\mathrm{E}}$ and a source of $\mathrm{C}$ losses that reduce NEP (Amiro et al.,

87 2010; Harmon et al., 2011; Russell et al., 2014; Woodall et al., 2015). How CWD progresses

88 through stages of decay and contributes to $\mathrm{R}_{\mathrm{E}}$ following more moderate disturbance is less clear,

89 though one recent study suggests that accounting for changes in CWD mass and respiration is

90 essential to interpreting how and why NEP may shift following lower intensity disturbances

91 (Renninger et al., 2014).

92 The motivation for studying forest $\mathrm{C}$, including CWD, dynamics across a range of

93 disturbance severities stems from observation and theory that suggests moderate disturbances

94 modify ecosystem structure and function differently than severe disturbances (Nave et al., 2011),

95 and these differences extend to CWD structure, mass and decomposition (Harmon et al., 2011).

96 Some moderate disturbances initially leave more CWD standing than downed, with implications

97 for woody debris microclimate and microbial colonization, and therefore microbial activity and

98 CWD respiration (Pedlar et al., 2002; Forrester et al., 2012; Forrester et al., 2013; Brazee et al.,

99 2014; Lewandowski et al., 2015; White et al., 2015). For example, partial defoliation of forest

100 canopies from insects increased standing dead wood mass, while severe disturbances such as

101 clear-cut harvesting and fire felled, removed, or reduced standing wood (Pedlar et al., 2002;

102 Renninger et al., 2014). Moreover, standing, but not downed, CWD has increased broadly in

Schmid et al. - Woody Debris in a Moderately Disturbed Forest, 5 
eastern US forests owing to patchy disturbance and natural tree senescence, with uncertain

104 consequences for the $\mathrm{C}$ cycle (Woodall et al., 2015). Yet, C cycling studies tend to focus on

105 downed rather than increasingly prevalent standing CWD, concluding the latter contributes

106 nominally to detritus pools and decays slowly, therefore contributing little to $\mathrm{R}_{\mathrm{E}}$ (Harmon et al.,

107 1986; Yatskov et al., 2003; Liu et al., 2006; Jomura et al., 2008; Tang et al., 2008). However, a

108 recent a recent study reported similar in situ respiration rates for standing and downed CWD,

109 with standing woody debris contributing substantially to $\mathrm{R}_{\mathrm{E}}$ (Renninger et al., 2014).

110 We evaluated CWD dynamics following a moderate forest disturbance at the University

111 of Michigan Biological Station (UMBS) in which all mature aspen (Populus) and birch (Betula)

112 were killed via experimental stem girdling but not immediately felled. The treatment produced a

113 forest structure and composition similar to that which is broadly emerging in the upper Great

114 Lakes region as secondary forests reach the century mark in age (Gough et al., 2010). The

115 experimental disturbance, which temporarily reduced live tree basal area by $39 \%$ and leaf area

116 index by $44 \%$, is similar in severity to increasingly prevalent naturally occurring disturbances in

117 the region (Gough et al., 2013). Prior C cycling studies resulting from this experiment

118 emphasized NEP, GPP and net primary production (NPP) following disturbance, demonstrating

119 sustained production in the moderately disturbed forest despite the experimental disturbance-

120 related transfer of $35 \mathrm{Mg} \mathrm{ha}^{-1}$ of wood from live to dead pools (Nave et al., 2011; Gough et al.,

121 2013; Stuart-Haentjens et al., 2015). Our prior emphasis on the unexpected resistance of forest

122 production to moderate disturbance revealed mechanisms underlying sustained $\mathrm{C}$ uptake, notably

123 improved canopy resource-use efficiency and the rapid reallocation of limiting nitrogen and light

124 resources in support of leaf area recovery. Here, we provide a first focus on C losses, asking

125 whether a large pulse of CWD that followed moderate disturbance was a prominent contributor

Schmid et al. - Woody Debris in a Moderately Disturbed Forest, 6 
126 to $\mathrm{R}_{\mathrm{E}}$ and, by extension, how this $\mathrm{C}$ lost by the ecosystem from CWD decomposition affects

127 NEP. Specific objectives were to: 1) examine multi-year changes in CWD pools through

128 moderate disturbance; 2) quantify in situ CWD respiration during different stages of decay for

129 downed and standing woody debris and; 3) calculate the annual contribution of CWD respiration

130 to the ecosystem $\mathrm{C}$ balance through comparison with $\mathrm{R}_{\mathrm{E}}$ and NEP. We hypothesized that the

131 large influx of CWD mass would constitute a substantial fraction of $\mathrm{R}_{\mathrm{E}}$ and, because the

132 disturbance did not cause the immediate felling of dead trees, standing woody debris would be

133 the principle contributor to the respiratory flux from CWD.

\section{2. Methods}

136 2.1 Site Description

137 The study was conducted at the University of Michigan Biological Station (UMBS) in 138 northern, lower Michigan, USA $\left(45^{\circ} 35 \mathrm{~N} 84^{\circ} 43 \mathrm{~W}\right)$. The site has a mean annual temperature of $1395.5^{\circ} \mathrm{C}$ and a mean annual precipitation of $817 \mathrm{~mm}$ (1942-2003) (Gough et al., 2013). The

140 UMBS forest is a representative secondary broadleaf deciduous forest in the transition zone 141 between temperate and boreal forests. The forest developed following a clear-cut and wildfire 142 regime in the early $20^{\text {th }}$ century and has since undergone only low severity, patchy disturbances.

143 Early successional species such as bigtooth aspen (Populus grandidentata), trembling aspen

144 (Populus tremuloides), and paper birch (Betula papyrifera) are nearing or past maturity and

145 senescing naturally, or in response to experimental disturbance described below. Canopy

146 dominance is shifting toward longer-lived, later successional species, including red oak (Quercus

147 rubra), red maple (Acer rubrum), and to a lesser extent, sugar maple (Acer saccharum) and

148 eastern white pine (Pinus strobus). The average overstory tree age is 100 years old (Gough et al.,

Schmid et al. - Woody Debris in a Moderately Disturbed Forest, 7 
149 2007). Downed woody debris represented a pool of $2.2 \mathrm{Mg} \mathrm{C} \mathrm{ha}^{-1}$ or $1.2 \%$ of total ecosystem C 150 prior to the decline of mature aspen and birch (Gough et al., 2007).

152 manipulation that was initiated in May 2008 to quantify how forest $\mathrm{C}$ pools and fluxes are

153 affected by moderate disturbance, ecological succession, and climate change. All early

154 successional aspen and birch trees $(\sim 6,700)$ were killed via stem girdling within a 39 ha area.

155 Carbon dioxide exchange between the atmosphere and the forest is continuously measured using 156 a meteorological tower established in 2007, with estimates of annual NEP and $R_{E}$ through 2013 157 reported by Gough et al. (2013) and Bond-Lamberty et al. (2015). Coarse woody debris mass, 158 respiration, and microclimate measurements, detailed below, occurred in the experimentally 159 disturbed area positioned within the meteorological flux tower footprint and no more than $300 \mathrm{~m}$ 160 away from the tower base.

\subsection{Coarse woody debris carbon mass}

In 2009, 2011, 2013, and 2014, downed coarse woody debris mass was inventoried by

164 decay class in eight, 0.1 ha subplots within the experimentally manipulated area. In the first

165 sampling year, all standing and downed CWD samples were tagged for repeated measures in

166 subsequent years of volume and decay class; newly produced CWD identified for the first time

167 in following sampling years was tagged and included in future inventories. Each inventory year,

168 all downed woody debris ( $>10 \mathrm{~cm}$ diameter, $<45^{\circ}$ from the forest floor) samples within a plot

169 were individually classified into one of the following decay classes (Marra and Edmonds, 1994):

170 (1) recently downed with bark and tissue fully intact, (2) sapwood is still present but beginning

171 to show signs of decay and bark may be beginning to peel or crack, (3) heartwood is intact, 
172 sapwood is present but softening, (4) heartwood is beginning to decay, sapwood and bark are

173 mostly gone, (5) heartwood shows signs of substantial decay, sapwood and bark are completely

174 missing. Standing woody debris ( $>45^{\circ}$ from the forest floor), which was identified as an

175 additional category of woody debris, was inventoried in the same plots as downed wood in 2011 176 and 2014.

177 We measured the length and diameter, at the ends and middle, of each piece of downed

178 CWD and measured total height, from sample base to top, and diameter at breast height of each

179 piece of standing woody debris. The surface area and volume of each piece of CWD were

180 calculated using the equation for the frustum of a cone (Harmon and Sexton, 1996). Site- and

181 species-specific wood densities and C concentrations for each decay class were used to calculate

182 C mass from CWD volume (Gough et al., 2007). In the case of standing CWD, which is difficult

183 to representatively sample without felling, we used the wood density and $\mathrm{C}$ fraction of downed

184 CWD, decay class 1 since values for these two categories are comparable (e.g., Koster et al., 185 2015).

\subsection{Coarse woody debris respiration and microclimate}

Instantaneous in situ respiration from the surface of aspen CWD $\left(\mathrm{R}_{\mathrm{CWD}} ; \mu \mathrm{mol} \mathrm{m} \mathrm{m}^{-2}\right)$

189 was repeatedly measured on downed and standing aspen CWD in the field during July and

190 August 2014. Though aspen and birch were both targeted in the disturbance experiment, aspen

191 comprised over $80 \%$ of the biomass stem girdled (Gough et al., 2010) and has similar decay

192 characteristics as birch (Russell et al., 2014); therefore, our analysis focused on aspen

193 respiration. Five PVC respiration collars ( $2 \mathrm{~cm}$ high, $10 \mathrm{~cm}$ diameter $)$ were permanently affixed

194 with duct seal putty to each of three replicate CWD samples $(>1.5 \mathrm{~m} \mathrm{long},>10 \mathrm{~cm}$ center

Schmid et al. - Woody Debris in a Moderately Disturbed Forest, 9 
195 diameter) per downed decay class and three standing CWD samples $(>10 \mathrm{~cm}$ diameter at breast

196 height). The five subsample collars were evenly spaced and positioned at random angles that did

197 not interfere with measurements along each CWD replicate, including the ends of downed

198 woody debris and the tops of standing woody debris when possible. For standing dead wood,

199 collar heights above the ground ranged from 1.2 to $12.5 \mathrm{~m}$. We measured $\mathrm{R}_{\mathrm{CWD}}$ weekly

200 beginning early July for downed CWD and mid-July for standing CWD through mid-August

201 using a Li-Cor LI-6400 Portable Photosynthesis System (Li-Cor, Lincoln, NE, USA). Wood

202 temperature $\left(1 \mathrm{~cm}\right.$ depth; $\left.\mathrm{T}_{\mathrm{CWD}}\right)$ and wood moisture $\left(12 \mathrm{~cm}\right.$ integrated depth; $\left.\phi_{\mathrm{CWD}}\right)$ were

203 measured concurrently with $\mathrm{R}_{\mathrm{CWD}}$ using a type-E thermocouple and a Campbell Scientific

204 HydroSense II soil moisture sensor (Model HS2-12, Campbell Scientific, Logan, UT, USA), 205 using a drill when necessary to produce holes for sensor placement in standing and downed

206 CWD. Wood water content was converted from volumetric to gravimetric values using site-

207 specific CWD densities (Gough et al., 2007).

208

2092.4 Annual carbon flux estimates

210 We estimated the annual respiratory $\mathrm{C}$ flux from downed and standing $\mathrm{CWD}\left(\mathrm{Mg} \mathrm{C} \mathrm{ha}{ }^{-1}\right.$

$\left.211 \mathrm{yr}^{-1}\right)$, hereafter termed ecosystem CWD respiration, for 2014 using three different methods. We

212 employed three different approaches because of the high uncertainty associated with estimates of

213 heterotrophic respiration (Harmon et al., 2011), focusing on 2014 because this was the year in

214 which we measured in situ CWD respiration. A mass balance estimate of ecosystem CWD

215 respiration was calculated as the change in total woody debris mass across all decay classes over

216 one year, from 2013 to 2014. Standing dead wood was inventoried in 2011 and 2014 only, with

217 mass values for 2013 estimated from linear interpolation between measurement years (Figure 1). 
218 In this approach, ecosystem CWD respiration is the summed or aggregate change in CWD mass,

219 including those that transitioned to a more advanced decay class. One limitation of this approach

220 is that, similar to other cohort-based mass balance approaches (e.g., Johnson et al., 2001), it does

221 not account for CWD production and losses occurring between inventories. The total annual loss

222 of C mass from CWD was assumed to be equal to the flux to the atmosphere, as CWD-C

223 leaching and export is considered negligible (Harmon et al., 1986; Laiho and Prescott, 1999). A

224 second approach integrated measured $\mathrm{R}_{\mathrm{CWD}}$ over time, with fluxes interpolated between

225 measurement dates. To estimate $\mathrm{R}_{\mathrm{CWD}}$ outside of the measurement period, we linearly

226 extrapolated fluxes to zero on the dates in the Spring and Autumn when temperatures $<0^{\circ} \mathrm{C}$;

227 winter $R_{\mathrm{E}}$ (all sources) is $<10 \%$ of the annual total at our site (Curtis et al., 2005). The

228 integrated area under the $\mathrm{R}_{\mathrm{CWD}}$ time series curve, shown in Figure 2a (illustrated without

229 extrapolated flux values), was calculated using SigmaPlot (SYSTAT Inc., San Jose, CA, USA).

230 We scaled fluxes to the ecosystem by multiplying integrated $\mathrm{R}_{\mathrm{CWD}}$ by the surface area of downed

231 and standing dead wood. Lastly, we used a published site- and species-specific model to infer

232 half-hourly $\mathrm{R}_{\mathrm{CWD}}$ from $\mathrm{T}_{\mathrm{CWD}}$ and $\phi_{\mathrm{CWD}}\left(R_{\mathrm{CWD}}=1.28 * e^{0.034^{*} T_{\mathrm{CWD}}}+0.25 * \ln \left({ }_{\mathrm{CWD}}\right) ; r^{2}=0.64, P<\right.$

233 0.001; Gough et al., 2007). Because continuous $\phi_{\mathrm{CWD}}$ and $\mathrm{T}_{\mathrm{CWD}}$ were required to model $\mathrm{R}_{\mathrm{CWD}}$

234 but not available from direct measurements, regressions between (3 to 4 per sample) point

235 measurements of $\phi_{\mathrm{CWD}}$ and $\mathrm{T}_{\mathrm{CWD}}$ and continuously (half-hourly) logged soil moisture and soil

236 temperature, respectively, were developed following the approach of Gough et al., 2007 to derive

237 continuous half-hourly estimates of $\phi_{\mathrm{CWD}}$ and $\mathrm{T}_{\mathrm{CWD}}$ for 2014 . Respiration was assumed to be

238 zero when $\mathrm{T}_{\mathrm{CWD}}$ was $<0^{\circ} \mathrm{C}$ (Gough et al., 2007). Half-hourly estimates of $\mathrm{R}_{\mathrm{CWD}}$ were summed

239 and multiplied by decay class specific CWD mass to estimate ecosystem CWD respiration.

240 Ecosystem CWD respiration was compared with published mean annual $\mathrm{R}_{\mathrm{E}}$ and NEP (2009- 
241 2013) obtained from meteorological tower measurements of the exchange of $\mathrm{CO}_{2}$ between the

242 forest and atmosphere (Gough et al., 2013; Bond-Lamberty et al., 2015); we report mean, rather

243 than single-year, $\mathrm{R}_{\mathrm{E}}$ because this derived $\mathrm{C}$ flux, made with relatively high uncertainty, did not

244 change significantly over time following disturbance (Gough et al., 2013), and therefore is a

245 higher confidence estimate with which to compare ecosystem CWD respiration.

\subsection{Statistical analysis}

Statistical differences over time and among decay classes in CWD pools, $\mathrm{R}_{\mathrm{CWD}}, \phi_{\mathrm{CWD}}$,

249 and $\mathrm{T}_{\mathrm{CWD}}$ were assessed using a repeated measures analysis of variance (ANOVA), with values

$250 \pm 1$ S.E. presented in the text. Multiple comparisons were made using post hoc Fisher's LSD

251 analysis, selected because our hypotheses were based on a priori knowledge of differences

252 among decay classes in CWD pools, fluxes, and microclimate from an earlier, more tightly

253 controlled field and laboratory manipulation conducted at our site prior to disturbance (Gough et

$254 a l ., 2007)$. Linear and non-linear (2-parameter exponential function) regression analysis was

255 used to examine decay class specific relationships between $\mathrm{R}_{\mathrm{CWD}}$, and both $\phi_{\mathrm{CWD}}$ and $\mathrm{T}_{\mathrm{CWD}}$

256 (Curtis et al., 2005; Gough et al., 2007) and standing woody debris measurement height, and

$257 \phi_{\mathrm{CWD}}$ and $\mathrm{R}_{\mathrm{CWD}}$. The uncertainty in each ecosystem CWD respiration estimate was expressed as

258 a standard error (S.E.) derived from the cumulative error in model parameters (model approach

259 only) and accounting for spatial variation in $\mathrm{R}_{\mathrm{CWD}}$ (integration approach only) and CWD mass

260 distribution (all approaches) (Gough et al., 2007). All statistical analyses used a significance

261 level of $\alpha=0.05$ and were performed in SAS (ANOVA; SAS 9.1, SAS Institute, Cary, NC,

262 USA) or SPSS (regression; IBM SPSS Statistics, version 22, IBM Corp., Armonk, NY, USA). 


\subsection{Coarse woody debris carbon pools}

The allocation of CWD among decay classes and the total mass of woody debris changed

267 over time following moderate disturbance. One year after the stem-girdling treatment, in 2009,

268 and prior to peak tree mortality, downed CWD mass was evenly distributed among decay

269 classes, totaling $0.3 \pm 0.09 \mathrm{Mg} \mathrm{Cha}^{-1}$ for all decay classes combined (Figure 1). By 2011, $97 \%$

270 of stem-girdled aspen and birch were defoliated and considered dead, resulting in a $35 \mathrm{Mg} \mathrm{Cha}^{-1}$

271 pulse of CWD from experimental disturbance (Gough et al., 2013) plus an additional 2.1 Mg C

$272 \mathrm{ha}^{-1}$ of naturally senesced CWD in early stages of decomposition, including standing dead wood.

273 In 2013 and 2014, following multiple years of decomposition, the mass of downed wood trended

274 upward as standing CWD began to fall and advance through stages of decay (Figure 1); this

275 increase over time was not statistically significant, (time main effect, $\mathrm{p}=0.27$; time $\mathrm{x}$ decay class

276 interaction, $\mathrm{p}=0.39$ ), however, because of the very high spatial variation among replicate plots

277 in CWD mass, a signature of disturbance-related increases in the spatial heterogeneity of C pools

278 and fluxes (Gough et al., 2013). Six years following disturbance in 2014, standing dead wood

279 remained the largest pool of CWD ecosystem-wide at $24.5 \pm 7.6 \mathrm{Mg} \mathrm{C} \mathrm{ha}^{-1}$; downed dead wood

280 comprised $1.5 \pm 0.7 \mathrm{Mg} \mathrm{Cha}^{-1}$.

\subsection{Coarse woody debris respiration and microclimate}

284 decay classes and over time (Figure $2 \mathrm{~A}$ ). Mean $\mathrm{R}_{\mathrm{CwD}}$ varied by an order of magnitude among

285 decay classes and across time, from $1.2 \mu \mathrm{mol} \mathrm{CO} \mathrm{CO}^{-2} \mathrm{~s}^{-1}$ to $11.4 \mu \mathrm{mol} \mathrm{CO} \mathrm{CO}^{-2} \mathrm{~s}^{-1}$, with

286 individual point measurements as high as $64.3 \mu \mathrm{mol} \mathrm{CO} \mathrm{CO}^{-2} \mathrm{~s}^{-1}$. In general, $\mathrm{R}_{\mathrm{CWD}}$ increased with 
287 increasing extent of decay (decay class main effect, $\mathrm{p}=0.008$ ), but significant pairwise

288 differences $(\mathrm{p}<0.05)$ were only observed between decay class 1 and decay classes 2, 4, and 5,

289 and decay class 5 and standing dead wood, decay class 1, and decay class 3. Notably, standing

290 dead wood and downed decay class 1 CWD had comparable $\mathrm{R}_{\mathrm{CWD}}$ (Figure 2A). Wood water

291 content, $\phi_{\mathrm{CWD}}$, increased with increasing extent of decay, up to decay class 4 (decay class main

292 effect, $\mathrm{p}<0.0001$ ) (Figure $2 \mathrm{~B}$ ). Wood temperature, $\mathrm{T}_{\mathrm{CWD}}$, increased with increasing extent of

293 downed wood decay (decay class main effect, $\mathrm{p}=0.04$ ), and was highest in downed decay

294 classes 4 and 5, and in standing dead wood (Figure 2C).

Although $\mathrm{T}_{\mathrm{CWD}}$ and $\phi_{\mathrm{CWD}}$ varied considerably over time and among decay classes,

296 temperature and moisture were not significant predictors of $\mathrm{R}_{\mathrm{CWD}}$ in downed wood;

297 contrastingly, mean moisture, which varied significantly by standing CWD height, was

298 correlated with $\mathrm{R}_{\mathrm{CWD}}$ in standing wood (Figure $3 \mathrm{~A}$ ). There was no significant relationship

299 between downed $\mathrm{R}_{\mathrm{CWD}}$, and either $\phi_{\mathrm{CWD}}$ or $\mathrm{T}_{\mathrm{CWD}}$ when each point measurement was treated as an

300 independent observation or when averaged across measurement dates for any decay class

301 individually or when all decay classes were combined ( $\mathrm{p}>0.1$; data not shown). In contrast to

302 downed CWD, standing dead wood exhibited a significant decline in mean $\phi_{\mathrm{CWD}}$, averaged

303 across dates, with increasing measurement height $\left(\mathrm{p}<0.0001, \mathrm{r}^{2}=0.77\right)$ (Figure $\left.3 \mathrm{~A}\right)$ and a

304 significant relationship between mean $\phi_{C W D}$ and mean $R_{C W D}\left(p=0.015, r^{2}=0.402\right)$ (Figure 3B).

3063.3 Annual carbon flux estimates

307 We used three different approaches to estimate the contribution of standing and downed

308 CWD respiration to ecosystem respiration, $\mathrm{R}_{\mathrm{E}}$, in 2014: a mass balance approach calculating

309 ecosystem CWD respiration from changes in C pools, a simple under the curve (Figure 2A)

Schmid et al. - Woody Debris in a Moderately Disturbed Forest, 14 
310 integration and scaling of mean in situ instantaneous CWD respiration from point measurements,

$311 \mathrm{R}_{\mathrm{CWD}}$, and a previously developed site-specific model driven by continuous $\phi_{\mathrm{CWD}}$ and $\mathrm{T}_{\mathrm{CWD}}$

312 estimations. Estimates of ecosystem CWD respiration from downed and standing dead wood

313 combined did not differ significantly among approaches, totaling $1.1 \pm 1.1 \mathrm{Mg} \mathrm{C} \mathrm{ha}^{-1} \mathrm{yr}^{-1}$ for the

314 mass balance approach, $2.1 \pm 1.3 \mathrm{Mg} \mathrm{C} \mathrm{ha}^{-1} \mathrm{yr}^{-1}$ for the integration approach, and 1.2 $\pm 1.6 \mathrm{Mg} \mathrm{C}$

$315 \mathrm{ha}^{-1} \mathrm{yr}^{-1}$ for the modeling approach. Standing dead wood was the largest contributor to ecosystem

316 CWD respiration in all estimations (Figure 4), comprising $65 \%, 57 \%$, and $74 \%$ of the total

317 annual CWD respiration from the mass balance, integration, and model estimates, respectively.

318 This large contribution from standing dead wood was a function of its high surface area relative

319 to downed wood (Figure 1) rather than high $\mathrm{R}_{\mathrm{CWD}}$. Decay class 2 downed woody debris was the

320 second largest source of respired C from CWD in all estimations. Total C flux from downed

321 woody debris classes $1,3,4$, and 5 contributed $<20 \%$ of the total ecosystem CWD respiration in

322 all estimations. Given total CWD mass $\left(26 \mathrm{Mg} \mathrm{C} \mathrm{ha}^{-1}\right)$ and ecosystem CWD respiration values

323 (1.1 to $2.1 \mathrm{Mg} \mathrm{C} \mathrm{ha}^{-1} \mathrm{yr}^{-1}$ ) six years following disturbance, the CWD decomposition rate-

324 constant (ecosystem CWD mass/ecosystem CWD respiration) was between 0.4 and $0.8 \mathrm{yr}^{-1}$.

325 Ecosystem CWD respiration (1.1 to 2.1 $\mathrm{Mg} \mathrm{C} \mathrm{ha}^{-1} \mathrm{yr}^{-1}$ ) following moderate disturbance

326 was a substantial contributor to $\mathrm{R}_{\mathrm{E}}$ and similar in magnitude, but opposite in sign, to NEP. Mean

$327 \mathrm{R}_{\mathrm{E}}$ following disturbance (2009-2013) was an $8.81 \pm 0.23 \mathrm{Mg} \mathrm{C} \mathrm{ha}^{-1} \mathrm{yr}^{-1}$ flux to the atmosphere

328 (Bond-Lamberty et al., 2015) and did not differ significantly over time or from a nearby

329 undisturbed, control forest (Gough et al., 2013). The different estimation approaches suggest that

330 ecosystem CWD respiration comprised $12.0-24.3 \%$ of the total respiratory C flux ecosystem-

331 wide 6 years following disturbance (Figure 4). Despite the mortality of > one-third of all canopy

332 trees, the ecosystem remained a modest $\mathrm{C}$ sink following disturbance, with mean NEP (= GPP - 
$333 \mathrm{R}_{\mathrm{E}}$ ) comparable to that of the control forest (Gough et al., 2013). Ecosystem CWD respiration

334 was only slightly lower in magnitude than mean NEP of $2.59 \pm 0.18 \mathrm{Mg} \mathrm{C}^{-1}$ following

335 disturbance (2009-2013) (Bond-Lamberty et al., 2015).

337 4. Discussion

We have shown that ecosystem CWD respiration was a substantial contributor to $\mathrm{R}_{\mathrm{E}}$, and

339 therefore a large $\mathrm{C}$ loss from the ecosystem, following a moderate forest disturbance,

340 approaching NEP in magnitude. Our results indicate that standing woody debris mass, though

341 spatially variable, was a particularly important contributor to the ecosystem's total CWD pool

342 and respiration following moderate disturbance, with in situ standing woody debris respiration

343 rates comparable to those of downed woody debris in the earliest stage of decay. Despite an

344 increase in ecosystem CWD respiration following tree mortality, comparable levels of $\mathrm{R}_{\mathrm{E}}$ before

345 and after disturbance, and relative to a nearby undisturbed control site suggest that the

346 respiratory contribution from other sources may have declined as ecosystem CWD respiration

347 increased, helping to stabilize NEP.

348 Our experimental disturbance was similar in severity to moderate disturbances caused by

349 insect defoliation, pathogen outbreaks, and extreme weather, resulting in a comparable input of

350 CWD. Our experiment gradually transferred $35 \mathrm{Mg} \mathrm{C} \mathrm{ha}^{-1}$ from live to dead wood pools, with

351 standing woody debris accounting for $>90 \%$ of the total CWD mass 6 years following

352 disturbance. This value is considerably higher than CWD pools of $2.2 \mathrm{Mg} \mathrm{C}^{-1}$ in a nearby

353 undisturbed forest (Gough et al., 2007) and of $0.3 \mathrm{Mg} \mathrm{C} \mathrm{ha}^{-1}$ one year following the disturbance

354 treatment. Sudden oak death similarly increased standing woody debris and total CWD mass

355 from 1.4 $\mathrm{Mg} \mathrm{Cha}^{-1}$ to $33.9 \mathrm{Mg} \mathrm{C} \mathrm{ha}^{-1}$ (Cobb et al., 2012). Gypsy moth defoliation increased 
356 CWD mass to a lesser extent, from $2.5 \mathrm{Mg} \mathrm{Cha}^{-1}$ to $11 \mathrm{Mg} \mathrm{Cha}^{-1}$ three years post-disturbance, 357 with standing woody debris making up $75 \%$ of dead wood mass (Renninger et al., 2014). and among decay classes, and across time, our measured values are similar to previously reported field measurements expressed on a surface area basis from our site and others (Gough et

361 al., 2007; Forrester et al., 2012; Renninger et al., 2014). Our observation of increasing $\mathrm{R}_{\mathrm{CWD}}$

362 with increasing extent of decay was previously observed at our site (Gough et al., 2007) and

363 others (Forrester et al., 2012; Renninger et al., 2014). In contrast, less decayed CWD respired at

364 a higher rate than more moderately decayed wood following pest-related mortality in an oak

365 forest (Renninger et al., 2014). Our inability to detect significant relationships between downed

$366 \mathrm{R}_{\mathrm{CWD}}$ and known microclimatic drivers (Zhou et al., 2007; Vanderhoof et al., 2013) was

367 associated with high variance in our field measurements, which are considerably more variable

368 than controlled laboratory based measurements of whole CWD pieces (Gough et al., 2007). Poor

369 correlations between $\mathrm{R}_{\mathrm{CWD}}$ and microclimate in the field may occur because $\mathrm{CO}_{2}$ emitted from

370 the CWD surface may originate far from the location of measurement and, therefore, be

371 decoupled from the local microclimate (Teskey et al., 2008). Nevertheless, we did detect a

372 relationship between $\mathrm{R}_{\mathrm{CWD}}$ and respiration collar height in standing dead wood, which

373 corresponded with differences in $\phi_{C W D}$.

$374 \quad$ Moderate disturbance caused a considerable increase in ecosystem CWD respiration

375 without a corresponding increase in total $\mathrm{R}_{\mathrm{E}}$ or a decrease in NEP, suggesting that the quantity

376 respired C from other sources may have declined and, in doing so, stabilized ecosystem C losses.

377 Though ecosystem CWD respiration estimates varied nearly 2-fold among the three approaches, 378 this level of variation among methods is typical of heterotrophic $\mathrm{C}$ fluxes, which are made with 
379 high uncertainty (Gough et al., 2008b; Harmon et al., 2011). Our estimates of ecosystem CWD 380 respiration before and after moderate disturbance suggest an increase from $0.2 \mathrm{Mg} \mathrm{C} \mathrm{ha}^{-1} \mathrm{yr}^{-1}$

381 (Gough et al., 2007) to a conservative estimate of $1.1 \mathrm{Mg} \mathrm{C} \mathrm{ha}^{-1} \mathrm{yr}^{-1}$, or from $2 \%$ to $12.5 \%$ of

$382 \mathrm{R}_{\mathrm{E}}$ six years after disturbance chiefly because of the increase in total downed and standing CWD

383 mass. An increase in ecosystem CWD respiration without a concomitant increase in $R_{E}$ suggests

384 that the contributions of other respiratory sources shifted by a similar amount but in the opposite

385 direction, stabilizing the total ecosystem respiratory $\mathrm{C}$ flux. Interestingly, this shift in the relative

386 contributions of different respiratory $\mathrm{C}$ fluxes parallels findings from our site demonstrating that,

387 following disturbance, a rapid compensatory increase in leaf photosynthesis and new growth by

388 undisturbed vegetation maintained ecosystem C uptake, thereby sustaining GPP and NPP despite

389 the mortality of more than a third of all canopy trees (Gough et al., 2013; Bond-Lamberty et al.,

390 2015; Stuart-Haentjens et al., 2015). Though we did not quantify respiration from other sources

391 in the current study, soil respiration, the primary contributor to $\mathrm{R}_{\mathrm{E}}$ in most ecosystems,

392 temporarily declined at our site and others following disturbance perhaps due to an initial

393 decrease in rhizosphere activity (Hogberg et al., 2001; Bhupinderpal et al., 2003; Nave et al.,

394 2011; Levy-Varon et al., 2012; Moore et al., 2013). Similarly, total plant respiration decreased

395 following pine-beetle disturbance because fewer live trees remained (Moore et al., 2013). Placed

396 within the broader context of prior results from our experimental disturbance, sustained NEP in

397 the first several years following moderate disturbance may be attributed to the maintenance of $\mathrm{C}$

398 uptake and primary production (Gough et al., 2013) and, given the present findings, stability in C

399 losses owing to compensatory shifts in respiratory sources that maintained, rather than increased,

$400 \quad \mathrm{R}_{\mathrm{E}}$. 
We found that standing woody debris, an often unmeasured source of respiratory C, was

402 the largest component of ecosystem CWD respiration, with relatively high in situ CWD

403 respiration rates. Respiration from standing dead wood is infrequently measured or accounted for

404 in ecosystem $\mathrm{C}$ budgets because it is assumed to be a small fraction of total CWD in recently

405 undisturbed ecosystems (Harmon et al., 2011), and have very low in situ respiration rates

406 (Harmon et al., 1986; Yatskov et al., 2003; Liu et al., 2006; Jomura et al., 2008; Tang et al.,

407 2008). However, recent region-wide forest inventories suggest standing dead wood pool size, in

408 contrast to downed CWD, is broadly increasing in aging forests of the Eastern US (Woodall et

$409 a l ., 2015)$. In our moderate experimental disturbance standing wood was a large fraction of the

410 total CWD pool, with in situ CWD respiration rates comparable to those for downed wood in

411 decay class 1 . Similarly, respiratory C losses from standing woody debris were substantial

412 following disturbances that initially left dead trees standing rather than felled and when in situ

413 standing CWD respiration rates were comparable to those of downed wood (Jomura et al., 2008;

414 Renninger et al., 2014).

415 The large remaining pool of CWD that originated following moderate disturbance

416 demonstrates the lasting, but presently uncertain, effect of disturbance on the forest's future C

417 cycle. Six years following disturbance, 26.0 $\mathrm{Mg} \mathrm{C} \mathrm{ha}^{-1}$ of mostly legacy woody debris remained

418 in the ecosystem, a large C pool approaching $15 \%$ of the ecosystem's total carbon stores (Gough

419 et al., 2008a). At present, the CWD decomposition rate-constant of 0.4 to $0.8 \mathrm{yr}^{-1}$ is slightly

420 lower than the $0.9 \mathrm{yr}^{-1}$ reported for our undisturbed, control forest (Gough et al., 2007) because

421 of the dominance of slowly decaying standing CWD in the disturbed forest. However, CWD

422 decomposition rate-constants, as the term implies, assume unchanged environmental conditions

423 and decomposer activity, an assumption that is violated by disturbance and which suggests the 
424 rate-constants we report here are likely to change in the future (Harmon et al., 2011; Russell et 425 al., 2014; Russell et al., 2015; Woodall et al., 2015). Nonetheless, aspen CWD can take > 70 426 years to fully decompose (Russell et al., 2014), suggesting that dead wood could remain a 427 source of $\mathrm{C}$ until the end of this century. Although respiration from decomposing CWD may 428 continue for decades, the contribution of ecosystem CWD respiration to $\mathrm{R}_{\mathrm{E}}$ is likely to change.

429 For example, respiration from other sources returned to pre-disturbance levels within several 430 years of an ecosystem perturbation (Levy-Varon et al., 2014; Trahan et al., 2015). However, 431 uncertainty exists in precisely when ecosystem CWD respiration will peak following 432 disturbance. A lag in time between disturbance and peak $\mathrm{R}_{\mathrm{E}}$ is commonly observed following 433 perturbations that do not immediately kill or fell trees (Harmon et al., 2011; Renninger et al., 434 2014). In our system, the abrupt felling of standing CWD from wind or ice, for example, could 435 accelerate decomposition and consequently increase ecosystem CWD respiration. Rates of dead 436 wood decomposition could also be affected by climate change, as the climate in northern lower 437 Michigan becomes warmer and drier with more variable precipitation (Duveneck et al., 2014; 438 Peterson et al., 2014).

439 We conclude that following a moderate severity forest disturbance the accounting of 440 downed and standing CWD pools and fluxes was essential to accurately quantifying the 441 ecosystem $\mathrm{C}$ budget, and interpreting the relative stability in $\mathrm{R}_{\mathrm{E}}$ and NEP following tree 442 mortality. Our findings are in agreement with those for a moderately disturbed oak forest 443 (Renninger et al., 2014), but contrast with many other studies demonstrating that CWD was 444 minimally important to the overall $\mathrm{C}$ budget during periods of low disturbance (Liu et al., 2006; 445 Gough et al., 2007; Tang et al., 2008). Standing woody debris, which our study suggests may 446 respire more than often assumed, may be an especially important $\mathrm{C}$ pool and flux to quantify 
447 following disturbances that do not immediately fell trees, such as insect defoliation, pathogen 448 outbreaks, and age-related senescence. Finally, our work here and that of others from our site 449 show that stability in the ecosystem C balance, NEP, during the first several years following

450 disturbance was tied not only to sustained C uptake and primary production (Gough et al., 2013;

451 Stuart-Haentjens et al., 2015) but also to unexpectedly stable $\mathrm{R}_{\mathrm{E}}$, despite a $\geq 5$-fold increase in 452 ecosystem CWD.

\section{Acknowledgements}

455 Funding for the UMBS AmeriFlux core site was provided by the U.S. Department of Energy's 456 (DOE) Office of Science and by the DOE Climate and Environmental Sciences Division, Office 457 of Science (Award Nos. DE-SC0006708, DE-SC0006708). EL was supported by a UMBS 458 Research Experience for Undergraduates (REU) program through NSF Award No. AGS459 0851421. We thank UMBS for facilities and logistical support, three anonymous reviewers for 460 their comments, and Drs. Rima Franklin, Scott Neubauer, and Julie Zinnert for reviewing our 461 manuscript. 
463 Amiro, B.D., Barr, A.G., Barr, J.G., Black, T.A., Bracho, R., Brown, M., Chen, J., Clark, K.L.,

464 Davis, K.J., Desai, A.R., Dore, S., Engel, V., Fuentes, J.D., Goldstein, A.H., Goulden, M.L.,

465 Kolb, T.E., Lavigne, M.B., Law, B.E., Margolis, H.A., Martin, T., McCaughey, J.H., Misson, L.,

466 Montes-Helu, M., Noormets, A., Randerson, J.T., Starr, G., Xiao, J., 2010. Ecosystem carbon

467 dioxide fluxes after disturbance in forests of North America. Journal of Geophysical Research-

468 Biogeosciences 115.

469 Bhupinderpal, S., Nordgren, A., Lofvenius, M.O., Hogberg, M.N., Mellander, P.E., Hogberg, P., 470 2003. Tree root and soil heterotrophic respiration as revealed by girdling of boreal Scots pine

471 forest: extending observations beyond the first year. Plant Cell and Environment 26, 1287-1296.

472 Bond-Lamberty, B., Fisk, J.P., Holm, J.A., Bailey, V., Bohrer, G., Gough, C.M., 2015. Moderate

473 forest disturbance as a stringent test for gap and big-leaf models. Biogeosciences 12, 513-526.

474 Bond-Lamberty, B., Peckham, S.D., Ahl, D.E., Gower, S.T., 2007. Fire as the dominant driver of 475 central Canadian boreal forest carbon balance. Nature 450, 89-+.

476 Brazee, N.J., Lindner, D.L., D'Amato, A.W., Fraver, S., Forrester, J.A., Mladenoff, D.J., 2014.

477 Disturbance and diversity of wood-inhabiting fungi: effects of canopy gaps and downed woody 478 debris. Biodiversity and Conservation 23, 2155-2172. 
479 Cobb, R.C., Chan, M.N., Meentemeyer, R.K., Rizzo, D.M., 2012. Common Factors Drive 480 Disease and Coarse Woody Debris Dynamics in Forests Impacted by Sudden Oak Death. 481 Ecosystems 15, 242-255.

482 Curtis, P.S., Vogel, C.S., Gough, C.M., Schmid, H.P., Su, H.B., Bovard, B.D., 2005. Respiratory 483 carbon losses and the carbon-use efficiency of a northern hardwood forest, 1999-2003. New 484 Phytologist 167, 437-455.

485 Duveneck, M.J., Scheller, R.M., White, M.A., Handler, S.D., Ravenscroft, C., 2014. Climate 486 change effects on northern Great Lake (USA) forests: A case for preserving diversity. Ecosphere 4875.

488 Forrester, J.A., Mladenoff, D.J., Gower, S.T., 2013. Experimental Manipulation of Forest 489 Structure: Near-Term Effects on Gap and Stand Scale C Dynamics. Ecosystems 16, 1455-1472.

490 Forrester, J.A., Mladenoff, D.J., Gower, S.T., Stoffel, J.L., 2012. Interactions of temperature and 491 moisture with respiration from coarse woody debris in experimental forest canopy gaps. Forest 492 Ecology and Management 265, 124-132.

493 Gough, C.M., Hardiman, B.S., Nave, L.E., Bohrer, G., Maurer, K.D., Vogel, C.S., Nadelhoffer, 494 K.J., Curtis, P.S., 2013. Sustained carbon uptake and storage following moderate disturbance in a 495 Great Lakes forest. Ecological Applications 23, 1202-1215. 
496 Gough, C.M., Vogel, C.S., Hardiman, B., Curtis, P.S., 2010. Wood net primary production

497 resilience in an unmanaged forest transitioning from early to middle succession. Forest Ecology 498 and Management 260, 36-41.

499 Gough, C.M., Vogel, C.S., Kazanski, C., Nagel, L., Flower, C.E., Curtis, P.S., 2007. Coarse 500 woody debris and the carbon balance of a north temperate forest. Forest Ecology and 501 Management 244, 60-67.

502 Gough, C.M., Vogel, C.S., Schmid, H.P., Curtis, P.S., 2008a. Controls on annual forest carbon 503 storage: Lessons from the past and predictions for the future. Bioscience 58, 609-622.

504 Gough, C.M., Vogel, C.S., Schmid, H.P., Su, H.B., Curtis, P.S., 2008b. Multi-year convergence 505 of biometric and meteorological estimates of forest carbon storage. Agricultural and Forest 506 Meteorology 148, 158-170.

507 Harmon, M.E., Bible, K., Ryan, M.G., Shaw, D.C., Chen, H., Klopatek, J., Li, X., 2004.

508 Production, respiration, and overall carbon balance in an old-growth Pseudotsuga-tsuga forest 509 ecosystem. Ecosystems 7, 498-512.

510 Harmon, M.E., Bond-Lamberty, B., Tang, J.W., Vargas, R., 2011. Heterotrophic respiration in 511 disturbed forests: A review with examples from North America. Journal of Geophysical 512 Research-Biogeosciences 116. 
513 Harmon, M.E., Franklin, J.F., Swanson, F.J., Sollins, P., Gregory, S.V., Lattin, J.D., Anderson,

514 N.H., Cline, S.P., Aumen, N.G., Sedell, J.R., Lienkaemper, G.W., Cromack, K., Cummins,

515 K.W., 1986. Ecology of coarse woody debris in temperate ecosystems. Advances in Ecological

516 Research 15, 133-302.

517 Harmon, M.E., Sexton, J., 1996. Guidelines for Measurements of Woody Detritus in Forest

518 Ecosystems. (US LTER Publication No. 20) US LTER Network Office, University of

519 Washington, Seattle, WA, USA.

520

521 Hicke, J.A., Allen, C.D., Desai, A.R., Dietze, M.C., Hall, R.J., Hogg, E.H., Kashian, D.M., 522 Moore, D., Raffa, K.F., Sturrock, R.N., Vogelmann, J., 2012. Effects of biotic disturbances on 523 forest carbon cycling in the United States and Canada. Global Change Biology 18, 7-34.

524 Hogberg, P., Nordgren, A., Buchmann, N., Taylor, A.F.S., Ekblad, A., Hogberg, M.N., Nyberg, 525 G., Ottosson-Lofvenius, M., Read, D.J., 2001. Large-scale forest girdling shows that current 526 photosynthesis drives soil respiration. Nature 411, 789-792.

527 Janisch, J.E., Harmon, M.E., 2002. Successional changes in live and dead wood carbon stores: 528 implications for net ecosystem productivity. Tree Physiology 22, 77-89.

529 Janisch, J.E., Harmon, M.E., Chen, H., Fasth, B., Sexton, J., 2005. Decomposition of coarse 530 woody debris originating by clearcutting of an old-growth conifer forest. Ecoscience 12, 151531160. 
532 Johnson, M.G., Tingey, D.T., Phillips, D.L., Storm, M.J., 2001. Advancing fine root research

533 with minirhizotrons. Environmental and Experimental Botany 45, 263-289.

534 Jomura, M., Kominami, Y., Dannoura, M., Kanazawa, Y., 2008. Spatial variation in respiration

535 from coarse woody debris in a temperate secondary broad-leaved forest in Japan. Forest Ecology

536 and Management 255, 149-155.

537 Koster, K., Metslaid, M., Engelhart, J., Koster, E., 2015. Dead wood basic density, and the 538 concentration of carbon and nitrogen for main tree species in managed hemiboreal forests. Forest 539 Ecology and Management 354, 35-42.

540 Laiho, R., Prescott, C.E., 1999. The contribution of coarse woody debris to carbon, nitrogen, and 541 phosphorus cycles in three Rocky Mountain coniferous forests. Canadian Journal of Forest 542 Research-Revue Canadienne De Recherche Forestiere 29, 1592-1603.

543 Levy-Varon, J.H., Schuster, W.S.F., Griffin, K.L., 2012. The autotrophic contribution to soil 544 respiration in a northern temperate deciduous forest and its response to stand disturbance.

545 Oecologia 169, 211-220.

546 Levy-Varon, J.H., Schuster, W.S.F., Griffin, K.L., 2014. Rapid rebound of soil respiration

547 following partial stand disturbance by tree girdling in a temperate deciduous forest. Oecologia $548 \quad 174,1415-1424$. 
549 Lewandowski, T.E., Forrester, J.A., Mladenoff, D.J., Stoffel, J.L., Gower, S.T., D'Amato, A.W.,

550 Balser, T.C., 2015. Soil microbial community response and recovery following group selection

551 harvest: Temporal patterns from an experimental harvest in a US northern hardwood forest.

552 Forest Ecology and Management 340, 82-94.

553 Liu, W.H., Bryant, D.M., Hutyra, L.R., Saleska, S.R., Hammond-Pyle, E., Curran, D., Wofsy,

554 S.C., 2006. Woody debris contribution to the carbon budget of selectively logged and maturing 555 mid-latitude forests. Oecologia 148, 108-117.

556 Luyssaert, S., Schulze, E.D., Borner, A., Knohl, A., Hessenmoller, D., Law, B.E., Ciais, P., 557 Grace, J., 2008. Old-growth forests as global carbon sinks. Nature 455, 213-215.

558 Marra, J.L., Edmonds, R.L., 1994. Coarse woody debris and forest floor respiration in an old559 growth coniferous forest on the Olympic Peninsula, Washington, USA. Canadian Journal of 560 Forest Research-Revue Canadienne De Recherche Forestiere 24, 1811-1817.

561 Moore, D.J.P., Trahan, N.A., Wilkes, P., Quaife, T., Stephens, B.B., Elder, K., Desai, A.R.,

562 Negron, J., Monson, R.K., 2013. Persistent reduced ecosystem respiration after insect 563 disturbance in high elevation forests. Ecology Letters 16, 731-737.

564 Nave, L.E., Gough, C.M., Maurer, K.D., Bohrer, G., Hardiman, B.S., Le Moine, J., Munoz, A.B., 565 Nadelhoffer, K.J., Sparks, J.P., Strahm, B.D., Vogel, C.S., Curtis, P.S., 2011. Disturbance and 566 the resilience of coupled carbon and nitrogen cycling in a north temperate forest. Journal of 567 Geophysical Research-Biogeosciences 116.

Schmid et al. - Woody Debris in a Moderately Disturbed Forest, 27 
568 Pan, Y.D., Birdsey, R.A., Fang, J.Y., Houghton, R., Kauppi, P.E., Kurz, W.A., Phillips, O.L.,

569 Shvidenko, A., Lewis, S.L., Canadell, J.G., Ciais, P., Jackson, R.B., Pacala, S.W., McGuire,

570 A.D., Piao, S.L., Rautiainen, A., Sitch, S., Hayes, D., 2011. A Large and Persistent Carbon Sink

571 in the World's Forests. Science 333, 988-993.

572 Pedlar, J.H., Pearce, J.L., Venier, L.A., McKenney, D.W., 2002. Coarse woody debris in relation

573 to disturbance and forest type in boreal Canada. Forest Ecology and Management 158, 189-194.

574 Peterson, D.L., Wolken, J.M., Hollingsworth, T.N., Giardina, C.P., Littell, J.S., Joyce, L.A.,

575 Swanston, C.W., Handler, S.D., Rustad, L.E., McNulty, S.G., 2014. Regional Highlights of

576 Climate Change. In: Peterson, D.L., Vose, J.M., PatelWeynand, T. (Eds.), Climate Change and

577 United States Forests, pp. 113-148.

578 Renninger, H.J., Carlo, N., Clark, K.L., Schaefer, K.V.R., 2014. Modeling respiration from snags

579 and coarse woody debris before and after an invasive gypsy moth disturbance. Journal of

580 Geophysical Research-Biogeosciences 119, 630-644.

581 Russell, M.B., Fraver, S., Aakala, T., Gove, J.H., Woodall, C.W., D'Amato, A.W., Ducey, M.J., 582 2015. Quantifying carbon stores and decomposition in dead wood: A review. Forest Ecology and 583 Management 350, 107-128.

584 Russell, M.B., Woodall, C.W., Fraver, S., D'Amato, A.W., Domke, G.M., Skog, K.E., 2014.

585 Residence Times and Decay Rates of Downed Woody Debris Biomass/Carbon in Eastern US

586 Forests. Ecosystems 17, 765-777.

Schmid et al. - Woody Debris in a Moderately Disturbed Forest, 28 
587 Stuart-Haentjens, E.J., Curtis, P.S., Fahey, R.T., Vogel, C.S., Gough, C.M., 2015. Net primary

588 production of a temperate deciduous forest exhibits a threshold response to increasing

589 disturbance severity. Ecology 96, 2478-2487.

590 Tang, J.W., Bolstad, P.V., Desai, A.R., Martin, J.G., Cook, B.D., Davis, K.J., Carey, E.V., 2008.

591 Ecosystem respiration and its components in an old-growth forest in the Great Lakes region of

592 the United States. Agricultural and Forest Meteorology 148, 171-185.

593 Teskey, R.O., Saveyn, A., Steppe, K., McGuire, M.A., 2008. Origin, fate and significance of $594 \mathrm{CO} 2$ in tree stems. New Phytologist 177, 17-32.

595 Trahan, N.A., Dynes, E.L., Pugh, E., Moore, D.J.P., Monson, R.K., 2015. Changes in soil 596 biogeochemistry following disturbance by girdling and mountain pine beetles in subalpine 597 forests. Oecologia 177, 981-995.

598 Vanderhoof, M., Williams, C., Pasay, M., Ghimire, B., 2013. Controls on the rate of CO2 599 emission from woody debris in clearcut and coniferous forest environments. Biogeochemistry $600114,299-311$.

601 White, S.D., Hart, J.L., Schweitzer, C.J., Dey, D.C., 2015. Altered structural development and 602 accelerated succession from intermediate-scale wind disturbance in Quercus stands on the 603 Cumberland Plateau, USA. Forest Ecology and Management 336, 52-64. 
604 Woodall, C.W., Russell, M.B., Walters, B.F., D'Amato, A.W., Fraver, S., Domke, G.M., 2015.

605 Net carbon flux of dead wood in forests of the Eastern US. Oecologia 177, 861-874.

606 Yatskov, M., Harmon, M.E., Krankina, O.N., 2003. A chronosequence of wood decomposition 607 in the boreal forests of Russia. Canadian Journal of Forest Research-Revue Canadienne De 608 Recherche Forestiere 33, 1211-1226.

609 Zhou, X., Wan, S.Q., Luo, Y.Q., 2007. Source components and interannual variability of soil 610 CO2 efflux under experimental warming and clipping in a grassland ecosystem. Global Change 611 Biology 13, 761-775.

612 


\section{Figure Captions}

614 Figure 1. Downed and standing woody debris carbon pools by decay class in a moderately

615 disturbed upper Great Lakes forest in which all aspen and birch trees were stem girdled in 2008.

616 Pool sizes reflect inputs from the experimental disturbance (35 $\mathrm{Mg} \mathrm{C} \mathrm{ha}^{-1}$ ) plus those from

617 naturally occurring tree senescence. Note the different y-axes and scales for downed (left) and

618 standing (right) woody debris. Means $\pm 1 / 4$ S.E. for visual clarity.

619

620 Figure 2. Means \pm 1 S.E. of in situ coarse woody debris respiration $\left(\mathrm{R}_{\mathrm{CWD}} ; \mathrm{A}\right)$, wood gravimetric

621 water content $\left(\phi_{\mathrm{CWD}} ; \mathrm{B}\right)$, and wood temperature $\left(\mathrm{T}_{\mathrm{CWD}} ; \mathrm{C}\right)$ of downed and standing woody debris 622 by decay class during Summer 2014.

624 Figure 3. Standing dead wood sample height in relation to mean wood water content ( $\phi_{\mathrm{CWD}}$; A) 625 and mean in situ coarse woody debris respiration $\left(\mathrm{R}_{\mathrm{CWD}}\right)$ in relation to mean wood water content

$626\left(\phi_{\mathrm{CWD}} ; \mathrm{B}\right)$. An outlier (half-filled circle), greater than two standard deviations from the mean,

627 was excluded from the regression analysis of mean $R_{C W D}$ and mean $\phi_{C W D}$. Means across sample 628 dates \pm 1 S.E.

630 Figure 4. Annual ecosystem CWD respiration, 2014, estimated using three different approaches 631 in comparison to mean net ecosystem production (NEP) and ecosystem respiration $\left(\mathrm{R}_{\mathrm{E}}\right)$ for a

632 Great Lakes forest, 2009-2013 by CWD decay class. Note that NEP and $\mathrm{R}_{\mathrm{E}}$ are expressed on a 633 separate $y$-axis and scale. Error bars are \pm 1 S.E. and represent cumulative uncertainty from 634 model error and spatial variation in the case of ecosystem CWD respiration, or meteorological 635 flux estimation for NEP and $\mathrm{R}_{\mathrm{E}}$ (see Gough et al. 2013). 


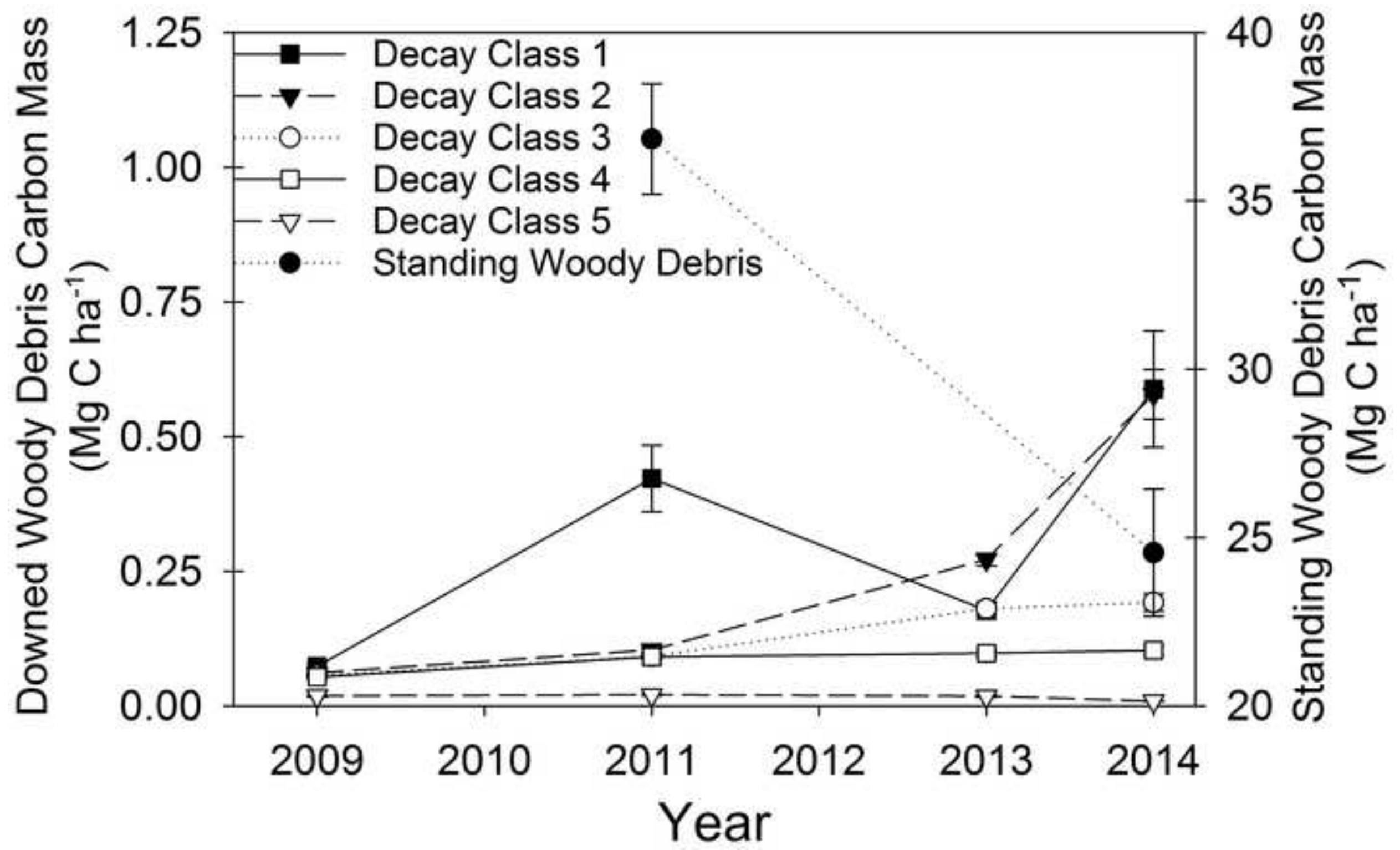




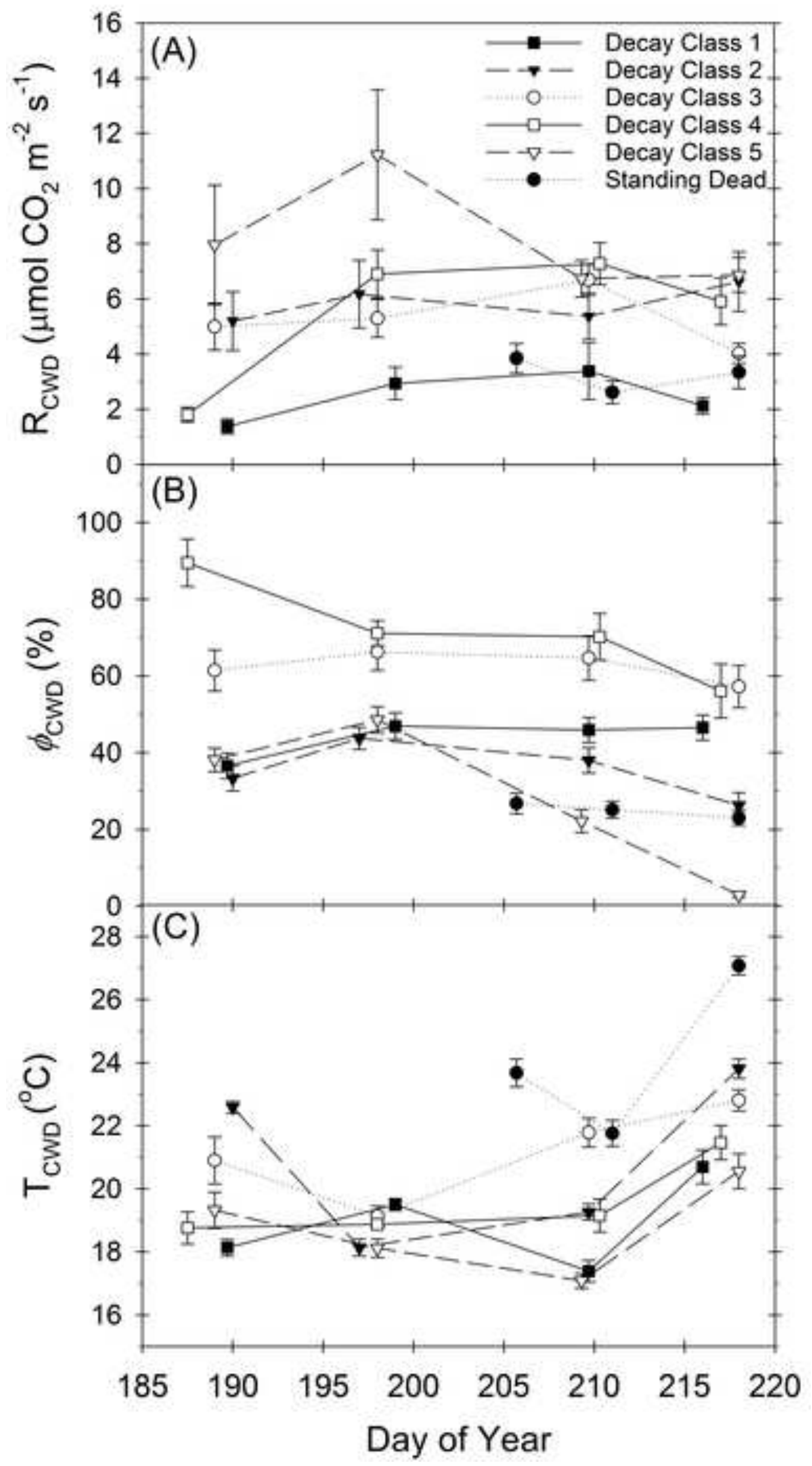




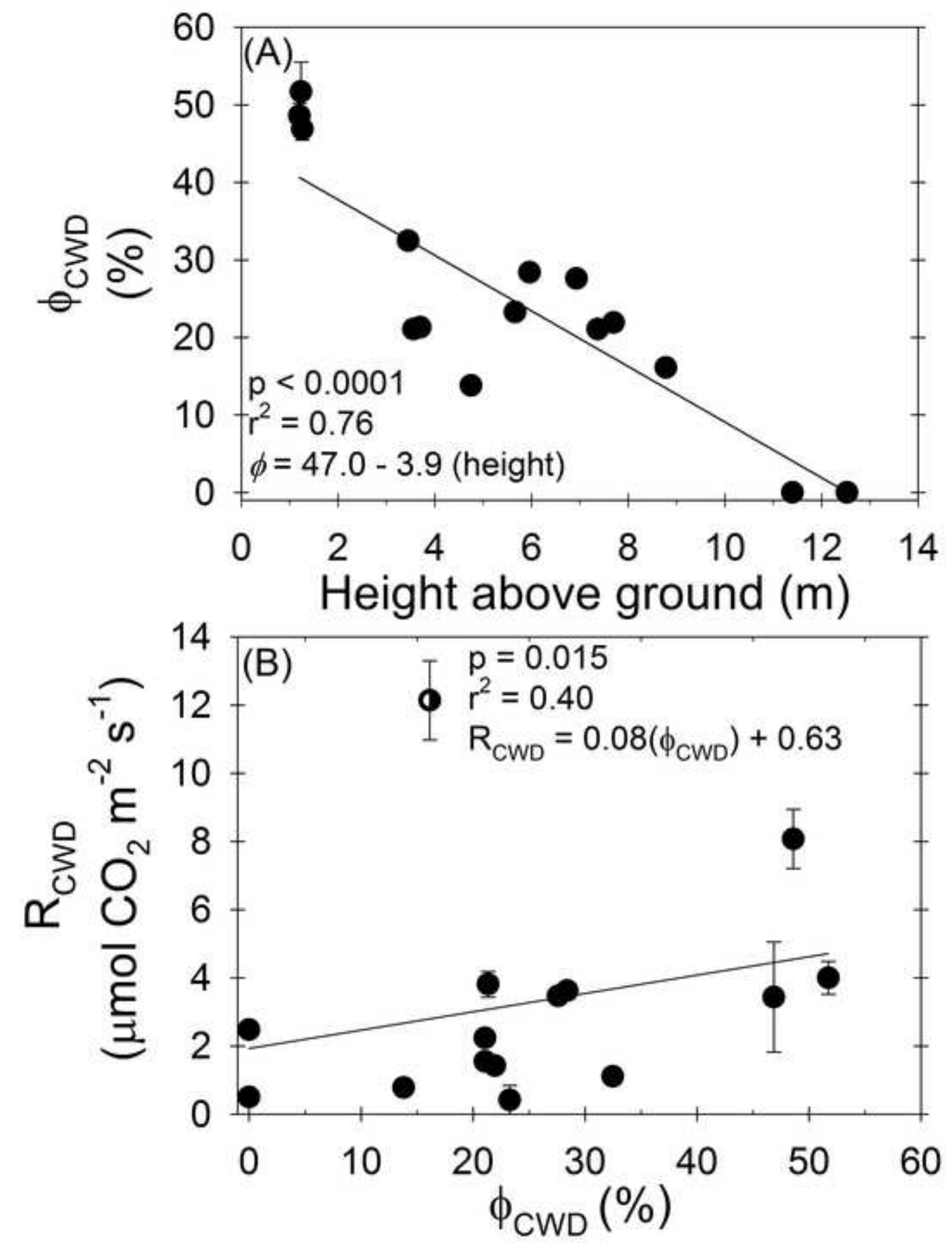

Figure 3 


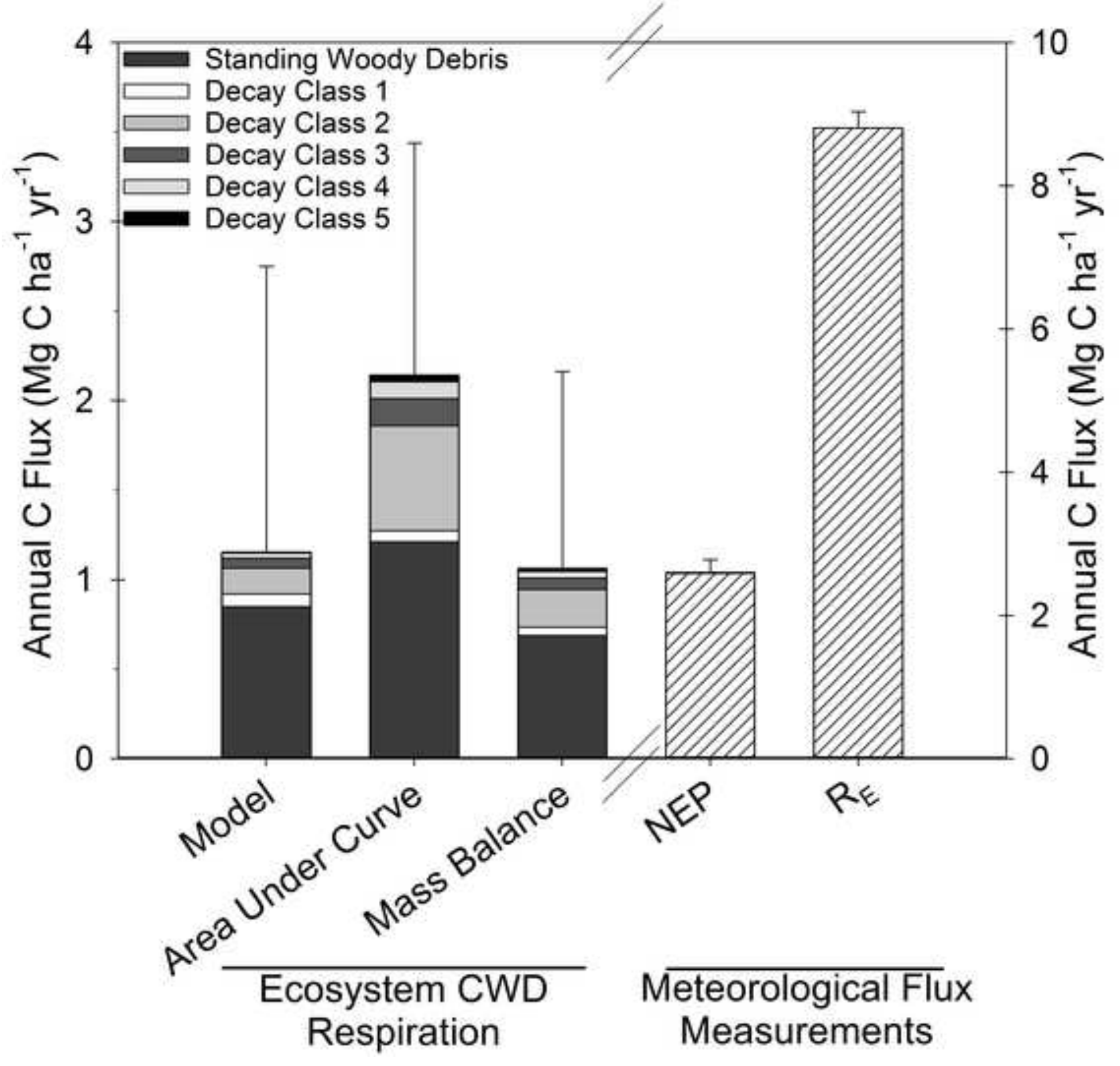

